\title{
Characterization of Copper Nanoparticles Synthesized by a Novel Microbiological Method
}

\author{
Ratnika Varshney, Seema Bhadauria, M.S. Gaur, and Renu Pasricha
}

The exploitation of various biomaterials for the biosynthesis of nanoparticles is considered as green technology as it does not involve any harmful chemicals. The present study reports the synthesis of copper nanoparticles which involves non-pathogenic bacterial strain Pseudomonas stutzeri, isolated from soil. These copper nanoparticles are further characterized for size and shape distributions by ultraviolet-visible spectroscopy, $x$-ray diffraction, and high resolution transmission electron microscopy techniques. The results showed that the particles are spherical and quite stable in nature and shows surface plasmon resonance clearly featured in the optical spectra in visible region.

\section{INTRODUCTION}

Low-dimensional nanoscale materials are currently of great interest due to their unique electronic, optical, and mechanical properties. ${ }^{1-4}$ Among the coinage metals, Ag and Au have been studied the most because of their stability and their intense absorption band in the visible region, often called surface plasmon absorption. $\mathrm{Cu}$, in turn, is the least studied out of the coinage metals due to its high instability for oxidation, and most of the time it forms complexes with water molecules in aqueous media., Particularly in transition metal oxides, $\mathrm{Cu}$-based nanoparticles and nanowires have been synthesized by a variety of methods, and because of a reduction in dimensionality, their ferromagnetic polarizations are quite different from those observed in transition metals. ${ }^{7-9}$ $\mathrm{Cu}$ nanoparticles were widely used as alternative catalysts, ${ }^{10}$ such as selective hydrogenation and methanol synthesis reactions, which make them suitable for application in the field of catalysis. Nano-sized $\mathrm{Cu}$ particles are widely used in fields of lubricants, polymers/plastic, metallic coating and ink. $\mathrm{Cu}$ sulfide has potential applications in solar cells, IR detectors and lubrication. ${ }^{11}$

There are several reports available of physical and chemical synthesis of $\mathrm{Cu}$ and $\mathrm{Cu}$ based nanomaterials. Chuncheng Hao et al. have reported the preparation of $\mathrm{Cu}$ nanoparticles encapsulated in graphitic carbon shells using modified arc plasma method. ${ }^{12}$ Surfactant-assisted electrochemical proce-

\section{How would you...}

एर

...describe the overall significance of this paper?

2

This paper reports a bacterial strain for the synthesis of copper nanoparticles. This is a novel method as it doesn't involve any harmful and environmentally

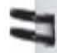
toxic chemicals used previously in conventional chemical reduction methods for the preparation of copper nanoparticles.

...describe this work to a materials science and engineering professional with no experience in E your technical specialty?

Copper nanoparticles synthesized with this method are spherical and well dispersed. They have organic coating on the surface which is reducing and not only acts as capping agent but also prevents them from oxidation, which seems to be a major problem with the previous methods involved in the copper nanoparticles synthesis.

...describe this work to a

\section{layperson?}

This method reports use of a nonpathogenic bacterial strain and spherical nanoparticles of copper are synthesized which are very useful in the field of catalysis. It is a simple, rapid, cost efficient and green method which is free from using any toxic reducing chemicals. This provides a platform for new metallic nanoparticles synthesis. dures have been shown to be a powerful tool for preparing stable nanoparticles composed of a wide range of metals and compounds. ${ }^{13-18}$ The most varied and versatile preparation route appears to be the so-called "sacrificial anode" electrolysis that is usually carried out in the presence of cationic surfactants such as tetra-alkyl-ammonium salts. In a seminal paper based on the combined use of transmission electron and scanning tunneling microscopies, the group of M. Reetz demonstrated that these metal nanoparticles possess a core-shell structure in which the metallic core is stabilized by a monolayer of tetra alkylammonium species, and the thickness of this shell is linearly correlated with the length of the alkyl chains. ${ }^{19}$ In the last decade, the electrolytic production of nanoparticles and nanocomposites containing platinum group elements has been extensively studied, due to the strong catalytic properties of these products. ${ }^{13,20-25}$ The electro-synthesis of $\mathrm{Cu}$ and $\mathrm{Ag}$ colloids, on the other hand, has been the subject of only a few reports. ${ }^{14,26-28}$ But no reports are available on the biological synthesis of $\mathrm{Cu}$ nanomaterials. It is, therefore, important to develop synthetic strategies that are simple, cost-effective, environment friendly, easily scalable and at the same time with parameters to control size and shape of the materials. Hence the development of a novel method for the preparation of $\mathrm{Cu}$ nanoparticles is inevitable. With these ideas in mind, an attempt has been made in this investigation to synthesize $\mathrm{Cu}$ nanoparticles by a novel biological method using non-pathogenic bacterial strain Pseudomonas stutzeri isolated from soil and characterize them for their properties by methods of absorption optical spectroscopy and transmission electron microscopy (HRTEM). 


\section{\begin{tabular}{ll}
\hline $\mathbf{b}$ & References
\end{tabular}}

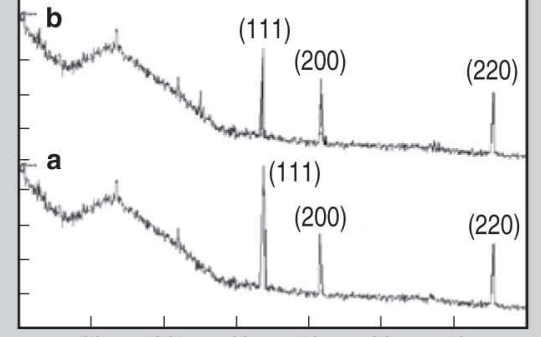

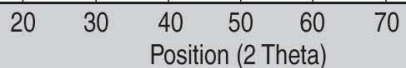

Figure 2. XRD patterns recorded from drop-coated films of $\mathrm{Cu}$ nanoparticles on glass substrates (a) after one $h$; (b) after one month.

stable even up to one month; since the $\mathrm{x}$-ray diffraction studies confirmed.

Figure $3 \mathrm{c}$ depicts the high magnification view of nanoparticles which shows lattice fringes on the surface, which is in good agreement with the inter-planar spacings of $\mathrm{Cu}$ (111). Inset of Figure $3 c$ shows the selected area electron diffraction (SAED) pattern obtained from the $\mathrm{Cu}$ nanoparticles. SAED depicts the Scherrer ring patterns, characteristic of the face centered cubic (fcc) $\mathrm{Cu}$, indicating that the structures seen in the HRTEM images are nanocrystalline in nature. From phase identification by transmission electron microscopy and $\mathrm{x}$-ray diffraction analysis, it was found that the $\mathrm{Cu}$ nanoparticles have been passivated and have not been oxidized in over one month.

\section{CONCLUSION}

We have prepared spherical $\mathrm{Cu}$ nanoparticles in nanoregime by a novel biological synthesis technique which is simple and environmentally benign. It is an easy, fast, and cost effective technique and doesn't involve any harmful and environmentally toxic chemicals used previously in conventional chemical reduction methods. Aqueous solutions of $\mathrm{Cu}$ nanoparticles with very good stability have been synthesized. It has been also discussed that the biomolecules present in the biomass not only reduce the metal ions and but also stabilize the metal nanoparticles by preventing them from being oxidized after the preparation. To the best of our knowledge, this is the first report of $\mathrm{Cu}$ nanoparticles synthesis using any bacterial strain.
1. T. Teranishi, I. Kiyokawa, and M. Miyake, Adv. Mater., 10 (1998), pp. 596-599.

2. H. Hori, T. Teranishi, Y. Nakae, Y. Seino, M. Miyake, and S. Yamada, Phys. Lett. A, 263 (1999), pp. 406-410. 3. J.M. Zuo, M. Kim, M. O'Keeffe, and J.C.H. Spence, Nature, 401 (1999), pp. 49-52.

4. E. Ruiz, S. Alvarez, P. Alemany, and R.A. Evarestov, Phys. Rev. B., 56 (1997), pp. 7189-7196.

5. B. Fox, O.P. Balaj, I. Balteanu, M.K. Beyer, and V.E. Bondybey, J. Am. Chem. Soc., 124 (2) (2002), pp 172-173.

6. P.V. Kazakevich, A.V. Simakin, V.V. Voronov, and G.A. Shafeev, Appl. Surf. Sci., 252 (2006), pp. 4373-4380.

7. H. Hori, Y. Yamamoto, T. Iwamoto, T. Miura, T. Teranishi, and M. Miyake, Phys. Rev. B., 69 (2004), pp. 174411-174416.

8. P. Crespo, R. Litrán, T.C. Rojas, M. Multigner, J.M. de la Fuente, J.C. Sánchez-López, M.A. Garciia, A. Hernando, S. Penadés, and A. Fernández, Phys. Rev. Lett., 93 (2004), pp. 087204-087207.

9. D. Craik, editor, Magnetism Principles and Applications (New York: John Wiley \& Sons, 1995), pp. $1-72$.

10. A.A. Setlur, J.M. Lauerhaas, J.Y. Dai, and R.P.H. Chang, Appl. Phys. Lett., 69 (1996), pp. 345-347.

11. R.S. Mane and C.D. Lokhande, Mater. Chem. Phys., 65 (1) (2000), p. 1.

12. Chuncheng Hao, Feng Xiao, and Zuolin Cui, J. Nanopart. Res., 10 (2008), pp. 47-51.

13. M.T. Reetz and W. Helbig, J. Am. Chem. Soc., 116 (1994), pp. 7401-7402.

14. M.V. Ten Kortenaar, Z.T. Kolar, and F.D. Tichelaar, J. Phys. Chem. B, 103 (1999), pp. 2054-2060.

15. S.S. Chang, C.W. Shih, C.D. Chen, W.C. Lai, and C.R. Chris Wang, Langmuir, 15 (1999), pp. 701-709.

16. M.B. Mohamed, Z.L. Wang, and M.A. El-Sayed, J. Phys. Chem. A, 103 (1999), pp. 10255-10259.

17. Y.Y.Yu, S.S. Chang, C.L. Lee, and C.R. Chris Wang, J. Phys. Chem. B, 101 (1997), pp. 6661-6664.

18. E. Kariv-Miller, P.D. Christian, and Ic.V. Svetlic, Langmuir, 11 (1995), pp. 1817-1821.

19. M.T. Reetz, W. Helbig, S.A. Quaiser, U. Stimming, N. Breuer, and R. Vogel, Science, 267 (1995), pp. 367-369.

20. N. Cioffi, L. Torsi, I. Losito, L. Sabbatini, P.G. Zambonin, and T. Bleve-Zacheo, Electrochim. Acta, 46 (2001), pp. 4205-4211.

21. M.T. Reetz, R. Breinbauer, and K. Wanninger, Tetrahedron Lett., 37 (1996), pp. 4499-4502.

22. M.T. Reetz, S.A. Quaiser, R. Breibauer, and B. Tesche, Angew Chem. (Int. Ed.), 23/24 (1995), pp. 2728-2730.

23. M.T. Reetz and S.A. Quaiser, Angew Chem. (Int. Ed.), 34 (1995), pp. 2240-2241.

24. V. Calo, A. Nacci, A. Monopoli, A. Fornaro, L. Sabbatini, N. Cioffi, and N. Ditaranto, Organometallics, 23 (2004), pp. 5154-5158.

25. M. Faticanti, N. Cioffi, S. De Rossi, N. Ditaranto, P. Porta, L. Sabbatini, and T. Bleve-Zacheo, Appl. Catal. B-Environ., 60 (2005), pp. 75-84.

26. N. Cioffi, L. Torsi, N. Ditaranto, L. Sabbatini, P.G. Zambonin, G. Tantillo, L. Ghibelli, M. D'Alessio, T. Bleve-Zacheo, and E. Traversa, Appl. Phys. Lett., 85 (2004), pp. 2417-2419.

27. L. Rodriguez-Sanchez, M.C. Blanco, and M.A. Lopez-Quintela, J. Phys. Chem. B, 104 (2000), pp. 9683-9688.

28. A. Dierstein, H. Natter, F. Meyer, H.O. Stephan, C. Kropf, and R. Hempelmann, Scripta Materialia, 44 (2001), pp. 2209-2212.

29. U. Kreibig and M. Vollmer, editors, Optical Properties of Metal Clusters (Berlin: Springer, 1995), pp. 207-234.

30. S. Link, C. Burda, B. Nikoobakht, and M.A. El-
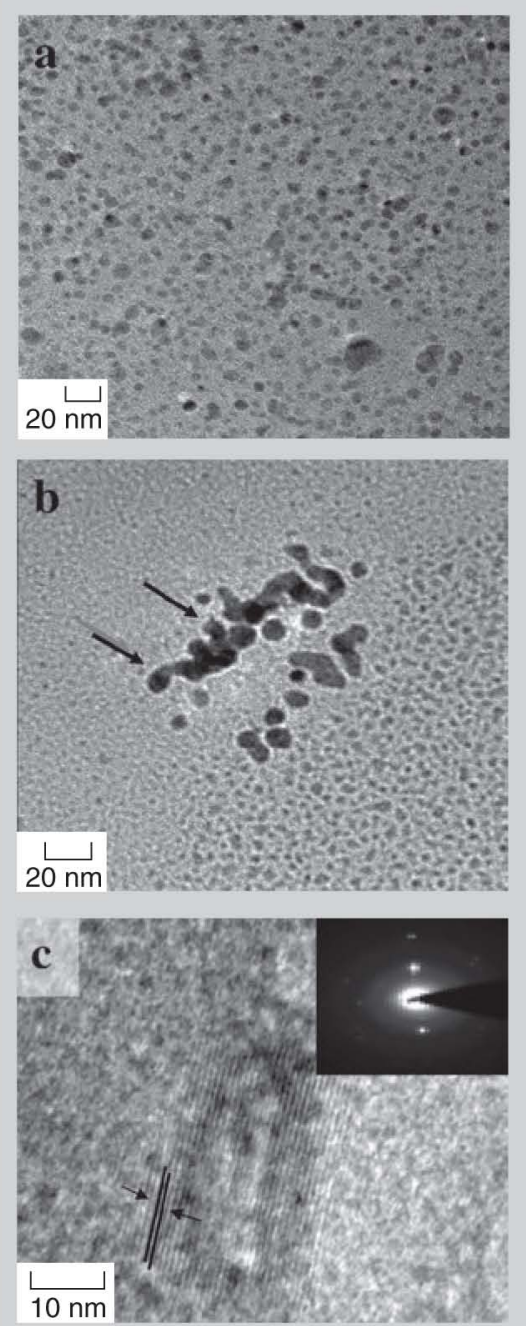

Figure 3. HRTEM images of $\mathrm{Cu}$ nanoparticles formed by bacteria Pseudomonas stutzeri shows: (a) spherical $\mathrm{Cu}$ nanoparticles; (b) a thin bacterial layer around nanoparticles which acts as capping agent; (c) close-up view of nanoparticles showing lattice fringes; inset shows selected electron diffraction pattern.

Sayed, J. Phys. Chem. B, 104 (2000), pp. 6152-6163. 31. M. Aslam, G. Gopakumar, T.L. Shoba, I.S. Mulla, K. Vijayamohanan, S.K. Kulkarni, J. Urban, and W. Vogel, J. Colloid. Inter. Sci., 255 (1) (2002), pp. 79-90.

32. K. Murai, Y. Watanabe, Y. Saito, T. Nakayama, H. Suematsu, W. Jiang, K. Yatsui, K.B. Shim, and K. Niihara, J. Ceramic Processing Research, 8 (2) (2007), pp. 114-118.

Ratnika Varshney, research scholar, and Seema Bhadauria are with the Microbiology and Nanotechnology Research Lab, Department of Botany, Raja Balwant Singh College, Khandari, Agra282004, India; M.S. Gaur, associate professor, is with the Department of Physics, Hindustan College of Science \& Technology, Farah, Mathura, India; and Renu Pasricha, scientist, is with the Electron Microscopy, Material Characterization Division, National Physical Laboratory, New Delhi. Varshney can be reached at ratisuccess@ gmail.com. 